\title{
RESENHA
}

\section{Por uma História Política dos Sistemas de Pensamento em Nietzsche e Foucault}

Towards a Political History of the System's of Thought in Nietzsche and Foucault

\author{
Rodrigo Diaz de Vivar Y Soler
}

Universidade Federal de Santa Catarina

Prado Filho, K. (2006). Michel Foucault: Uma história política da verdade. Florianópolis/Rio de Janeiro: Insular/Achiamé.

Tradicionalmente a epistemologia entende como científico todo conhecimento relativo às verdades universalizantes sobre um objeto enunciado pela figura do sujeito cognoscente. Neste sentido, ocorre uma dicotomização entre sujeito $\mathrm{x}$ objeto a partir da suposta neutralidade científica na qual a verdade ocupa um sentido central, e onde atingi-la significa uma "...meta pela qual são prometidas recompensas intelectuais, morais, religiosas e metafísicas." (Abel, 2002, p. 15).

O sujeito cognoscente deriva da noção kantiana de sujeito transcendental, ou seja, aquele que é capaz de apropriar-se de todas as regras de produção de conhecimento produzindo verdades irrefutáveis em torno do objeto investigado. No livro Michel Foucault: Uma História Política da Verdade, Prado Filho (2006), afirma que a modernidade é "a idade do homem". Tal afirmação sugere que nesse momento histórico toda questão relativa ao conhecimento se refere ao sujeito, mas não o sujeito cognoscente e sim outra categoria atravessada pelas relações de poder e produções discursivas. Prado Filho (2006) parte de uma problematização cujas ressonâncias estão inscritas nas perspectivas foucaultiana e nietzscheana de desconstrução tanto da noção de Epistemologia quanto a de Verdade. A partir de um ponto de vista genealógico, pergunta-se o autor: Os projetos de Nietzsche e Foucault seriam uma alternativa aos pressupostos epistemológicos tradicionais, ou se apresentam enquanto uma recusa a esses modelos? Para elucidarmos tal questionamento tratemos, pois, de analisar os pressupostos de análise histórica tanto em Foucault quanto em Nietzsche.

Em Foucault, o sentido da história corresponde à análise das formas de pensamento e das produções de conhecimento. Neste sentido, uma "episteme" em Foucault seria a produção do saber, a partir de diferentes momentos históricos os quais envolvem modos de operação, procedimentos e regimes que avalizam diferentes verdades em distintas épocas. A "episteme" moderna, por exemplo, que preconiza a razão como via de acesso ao conhecimento seguro e confiável, deriva do século XVIII. Segundo Prado Filho (2006), nos livros As Palavras e as Coisas e História da Loucura na Idade Clássica, Foucault apresenta dois outros modelos de epistemologia: uma proveniente da idade clássica referente ao século XVII, cuja principal característica não passava pela explicação racional das coisas, mas sim por uma intensa classificação dos objetos segundo regras e campos do saber e uma segunda proveniente do renascimento que operava sob o signo da exegese, possuindo como principal característica a decifração da sagrada escritura. Ali o campo de operação do saber correspondia ao dogmatismo e ao hermetismo.

Como pode-se observar, o campo epistemológico em sua historicidade é recoberto por diferentes possibilidades de entendimento em relação ao saber e as formas de operações de verdade. Então uma proposta de investigação arqueológica dos sistemas de pensamento deve percorrer as condições de possibilidade e emergência dos acontecimentos não a partir da suas origens ou unidades, mas sim no contexto das suas rupturas e descontinuidades.

Já em relação a Nietzsche, uma analítica histórica se refere à problematização do conhecimento, pondo-o em xeque a partir do questionamento dos valores. Seria uma pergunta nietzscheana a seguinte: nossos valores e nossas formas de conhecer provêm de uma moral aristocrática, e, portanto, afirmativa da vida, ou correspondem a uma moral gregária e negadora da vida? No prólogo de $A$ Genealogia da Moral, Nietzsche nos convida a experienciar o conhecimento sob um aspecto diferenciado, isto é, em vez de o concebermos como uma meta, como um fim, é preciso 
... praticar desse modo à leitura como arte, faz-se preciso algo que precisamente em nossos dias está bem esquecido - e que exigirá tempo até que minhas obras sejam legíveis - para o qual é imprescindível ser quase uma vaca, e não um "homem moderno": o ruminar... (1998, pp. 14-15).

Para Nietzsche (1998), a proposta se insere em uma renúncia do modelo de ciência moderna, pois esta traz consigo os elementos característicos de uma moral cristã, em seus discursos e suas práticas.

Prado Filho (2006), expõe que as conexões que ligam tanto as trajetórias arqueológicas e genealógicas de Foucault, quanto à genealogia nietzscheana correspondem à produção do conhecimento tomado não como algo útil e verdadeiro, mas sim como um processo discursivo que assujeita, e infere uma articulação entre o poder e o saber. E nesse sentido, da correlação entre Foucault e Nietzsche não nasce uma proposta epistemológica relativista ao modelo científico/hegemônico aos moldes de Thomas Kuhn (1987), por exemplo, mas sim uma contra-epistemologia referente ao questionamento do estatuto da verdade. Isto quer dizer, que tanto Nietzsche quanto Foucault em seus trabalhos, não fundam uma crítica relativista, justamente pelo fato de que o enfoque arqueológico e o genealógico instauram o perspectivismo que problematiza, desmente, transforma em humanos valores e verdades consideradas dogmáticas.

Ou seja, o perspectivismo desloca o campo de análise do universal, do plano metafísico para a esfera das minúcias dos jogos de verdade, inerente às relações de força e dos dispositivos de poder. Correlativo a ideia do perspectivismo como possibilidade de construção de uma contra-epistemologia, poder-se-ia delimitar a inserção do conceito de "interpretação" em Nietzsche e em Foucault. Considera-se tal conceito importante uma vez que ele se refere não ao deciframento dos signos, nem do desvelamento daquilo que é oculto, mas sim como possibilidade de estratégia de poder. Pois, segundo Foucault (2005, p. 260), “...interpretar é apoderar-se, pela violência ou sub-recepção, de um sistema de regras que não tem em si a significação essencial e impor-lhe uma direção, do- brá-lo a uma nova vontade, fazê-lo entrar num jogo e submetê-lo a novas regras."

O sentido da palavra interpretação em Foucault segue os pressupostos da terminologia nietzschiana principalmente no que diz respeito ao fato de que a interpretação se exerce em um movimento filológico cujas camadas estão presentes em apropriações e atribuições de sentidos a tudo o que pode ser nomeado através de intensas relações de força. Na perspectiva de Foucault e Nietzsche o conhecimento não é mais do que uma invenção canhestra. Tal afirmativa diz respeito ao fato de que ele não tem uma origem, que não está presente na natureza do sujeito, mas sim deriva do jogo, do enfrentamento presente nas práticas sociais.

Em seu livro, Prado Filho (2006), traz uma apresentação desse esfacelamento a partir de uma leitura transversal de Michel Foucault e Nietzsche com base numa contextualização política. Nesse sentido uma fala de Foucault $(2003$, p. 22) referente ao conhecimento enquanto processo de luta pode ser aqui destacada enquanto reflexão final: "Não, há, portanto, no conhecimento uma adequação ao objeto, uma relação de assimilação; não há no conhecimento algo como felicidade e amor, mas ódio e hostilidade; não há unificação, mas sistema precário de poder."

\section{REFERÊNCIAS}

Abel, G. (2002). Verdade e interpretação. Cadernos Nietzsche, $1(12), 15-33$.

Foucault, M. (2003). A verdade e as formas jurídicas (R. Machado $\&$ E. J. Morais, Trads.) ( $3^{\text {a }}$ ed.). Rio de Janeiro: NAU.

Foucault, M. (2005). Nietzsche, a genealogia e a história. Em M. B. da Motta (Org.), Ditos e escritos: Vol. II. Arqueologia das ciências e história dos sistemas de pensamento (pp. 260-281) (E. Monteiro, Trad.) ( $2^{\mathrm{a}}$ ed.). Rio de Janeiro: Forense Universitária.

Kuhn, T. S. (1987). A estrutura das revoluções científicas (B. Vianna \& N. Boeira, Trads.) (2 ed.). São Paulo: Perspectiva.

Nietzsche, F. (1998). Genealogia da moral: Uma polêmica. (P. C. de Souza, Trad.) São Paulo: Companhias das Letras.

Prado Filho, K. (2006). Michel Foucault: Uma história política da verdade. Florianópolis/Rio de Janeiro: Insular/Achiamé.

Recebido: 10/04/2008

Última revisão: 26/11/2009

Aceite final: 28/11/2009

\section{Sobre o autor da resenha:}

Rodrigo Diaz de Vivar Y Soler: Bacharel em Psicologia pela UNESC. Aluno do Programa de Pós-Graduação em Psicologia pela UFSC.

Endereço para correspondência: Rua Vereador Mario Coelho Pires, n. 221/1302, Bloco A - São José/SC - Endereço eletrônico: diazsoler@gmail.com 